\title{
Characterization and Expression Profiling of Neuropeptides and G-Protein-Coupled Receptors (GPCRs) for Neuropeptides in the Asian Citrus Psyllid, Diaphorina citri (Hemiptera: Psyllidae)
}

\author{
Zhengbing Wang ${ }^{1}\left(\mathbb{D}\right.$, Wenwu Zhou ${ }^{2}$, Muhammad Salman Hameed ${ }^{3}$, Jiali Liu ${ }^{1}$ \\ and Xinnian Zeng ${ }^{1, *}$ \\ 1 Guangdong Engineering Research Center for Insect Behavior Regulation, College of Agriculture, \\ South China Agricultural University, Guangzhou 510642, China; wangzi191@yahoo.com (Z.W.); \\ Shirley4462@scau.edu.cn (J.L.) \\ 2 State Key Laboratory of Rice Biology; Institute of Insect Sciences, Zhejiang University, \\ Hangzhou 310058, China; wenwuzhou@zju.edu.cn \\ 3 Department of Plant Protection, Faculty of Agricultural Sciences, Ghazi University, \\ Dera Ghazi Khan 32200, Pakistan; msuleman2941@yahoo.com \\ * Correspondence: zengxn@scau.edu.cn; Tel.: +86-20-85288356
}

Received: 18 November 2018; Accepted: 3 December 2018; Published: 6 December 2018

\begin{abstract}
Neuropeptides are endogenous active substances that widely exist in multicellular biological nerve tissue and participate in the function of the nervous system, and most of them act on neuropeptide receptors. In insects, neuropeptides and their receptors play important roles in controlling a multitude of physiological processes. In this project, we sequenced the transcriptome from twelve tissues of the Asian citrus psyllid, Diaphorina citri Kuwayama. A total of 40 candidate neuropeptide genes and 42 neuropeptide receptor genes were identified. Among the neuropeptide receptor genes, 35 of them belong to the A-family (or rhodopsin-like), four of them belong to the B-family (or secretin-like), and three of them are leucine-rich repeat-containing G-protein-coupled receptors. The expression profile of the 82 genes across developmental stages was determined by qRT-PCR. Our study provides the first investigation on the genes of neuropeptides and their receptors in $D$. citri, which may play key roles in regulating the physiology and behaviors of D. citri.
\end{abstract}

Keywords: Diaphorina citri; expression profiling; G-protein-coupled receptors; transcriptome; neuropeptides; phylogenetic tree

\section{Introduction}

The central nervous system (CNS) and its neuropeptide messengers rank the highest in the entity level regulating endogenous biochemical control function [1]. Neuropeptides are a diverse set of signaling molecules in multicellular organisms. In insects, neuropeptides play a significant role in the regulation of fundamental events such as development, reproduction, feeding, courtship, olfaction, circadian rhythm, and many other processes [2,3]. Neuropeptides are processed from their larger, inactive precursors by enzymes [4], up activation, and then work on target cells by binding to the specific signal-transducing membrane receptors [5]. Most of these receptors are subordinate to the G-protein-coupled receptors (GPCRs), and the GPCRs have a similar topographical structure with seven transmembrane domains which are highly conservative through evolution and constitute the largest superfamily of cell surface proteins [6]. In vivo studies showed that neuropeptides and their receptors appear to have key roles in the regulation of physiology and behavior in insects; injection of 
kinin caused a significant reduction in weight gain and an increased mortality in Heliothis virescens [7], injection of tachykinin (TK) resulted in diminished olfactory responses in electroantennograms of Periplaneta americana [8], reduced levels of the receptor of TK in Drosophila melanogaster olfactory receptor neurons (ORNs) showed increased attraction to two food-related odors [9]. Neuropeptides and their receptors regulate the fundamental events in insect life cycle, hence, they were proposed as potential insecticides or targets to replace or complement neurotoxic compounds [10]. Owing to the sequence specificity of these molecules and the specific receptor, neuropeptide-based compounds would be species-specific, and safe for non-target species. Moreover, resistance is not easy to develop, since a potential mutation in a neuropeptide precursor or receptor gene is typically detrimental [11].

The Asian citrus psyllid, Diaphorina citri Kuwayama (Hemiptera: Psyllidae), is one of the most important insect pests of citrus worldwide. It is the principal vector of Candidatus Liberibacter asiaticus (CLas), a phloem-inhabiting bacterium, which correlates with Huanglongbing (HLB) [12]. Huanglongbing, also known as citrus greening disease, poses the most destructive threat to citrus production worldwide with no known cure [13-15]. At present, the main ways to prevent and restrain the spread of the disease are employing chemical insecticides to control the vector; however, the application of conventional insecticides, including organophosphates, pyrethroids, and neonicotinoids, has led to the evolution of resistance to pesticides [16-18]. The primary means of blocking the transmission of HLB is to control D. citri, the vector of the pathogen; however, the development of insecticide resistance in $D$. citri also poses increased challenges for the persistent effectiveness of chemical control strategies. Furthermore, the more use of pesticides can also lead to problems with "resurgence" and "residue". Pesticides with safe and novel ways of action are needed to alleviate the problems of pesticide resistance and environmental pollution. The primary task of developing neuroendocrine-based insecticides is to identify the structure and function of neuropeptides and the receptors involved in survival, development, and/or reproduction [11].

Previous studies have identified the neuropeptides or neuropeptide receptors in D. melanogaster [3], Bombyx mori [19], Chilo suppressalis [20], Tribolium castaneum [21], Apis mellifera [22], Nilaparvata lugens [23], and Rhodnius prolixus [24]. However, the neuropeptides and their GPCRs in $D$. citri are poorly characterized. For these reasons, in this study, to identify gene-encoding neuropeptides and the receptors of neuropeptides in D. citri, we analyzed the transcriptomes in twelve tissues of this pest. The expression profiles of these neuropeptides and the receptors were validated by quantitative real time-PCR (qRT-PCR). This is the first study on the neuropeptides and neuropeptide receptors of $D$. citri, and these results provide valuable information to develop an integrated pest management program for the Asian citrus psyllid.

\section{Results}

\subsection{Sequencing and Unigene Assembly}

A total of $143.37 \mathrm{~Gb}$ of raw data was acquired, and after removing low-quality, adaptor, and contaminated sequence reads, yielded $137.22 \mathrm{~Gb}$ of clean reads. These clean reads were assembled into $38,161,895$ contigs (N50 $=48$ ) of an average length of 50 bp by Trinity. Then we obtained 297,614 unigenes larger than $200 \mathrm{bp}$ (N50 = 731) from non-redundant putative contigs, with a mean length of $575 \mathrm{bp}$. For annotations, the unigenes were searched against Nr (NCBI non-redundant protein sequences, http:/ / www.ncbi.nlm.nih.gov/), Swiss-Prot (a manually annotated and reviewed protein sequence database, http://www.expasy.ch/sprot/), KEGG (Kyoto Encyclopedia of Genes and Genomes, http:/ / www.genome.jp/kegg/), COG (Clusters of Orthologous Groups of proteins, http:/ / www.ncbi.nlm.nih.gov/COG/), and GO (Gene Ontology, http:/ /www.geneontology.org/) databases using BLASTx (search protein databases using a translated nucleotide query) with a cut-off E value of $10^{-5}$. As a result, 60,401 (20.29\%) were annotated using the NCBI-Nr database; $34,380(11.55 \%)$ by Swiss-Prot; 11,837 (3.98\%) by KEGG; 30,808 (10.35\%) by COG; $8691(2.92 \%)$ by GO, which covered $60,999(20.49 \%)$ of the total unigenes. Of the 297,614 unigenes, $8691(2.92 \%)$ matched at least one 
GO term (Figure 1). Among these unigenes, 13,536, 11,569, and 10,489 transcripts were assigned to biological processes, molecular function, and cellular component, respectively. Cellular process and metabolic processes represented the most abundant GO terms in the biological process category, binding and catalytic activity were most represented in molecular function, and the most unigenes that accorded with the cellular component category were involved in cell parts and organelles (Figure 1). The raw data of the transcriptomic were submitted to the NCBI Short Read Archive (SRA) database as BioProject Accession Number SRP139008 (https:/ / www.ncbi.nlm.nih.gov/sra/SRP139008).

\section{Gene Function Classification (GO)}

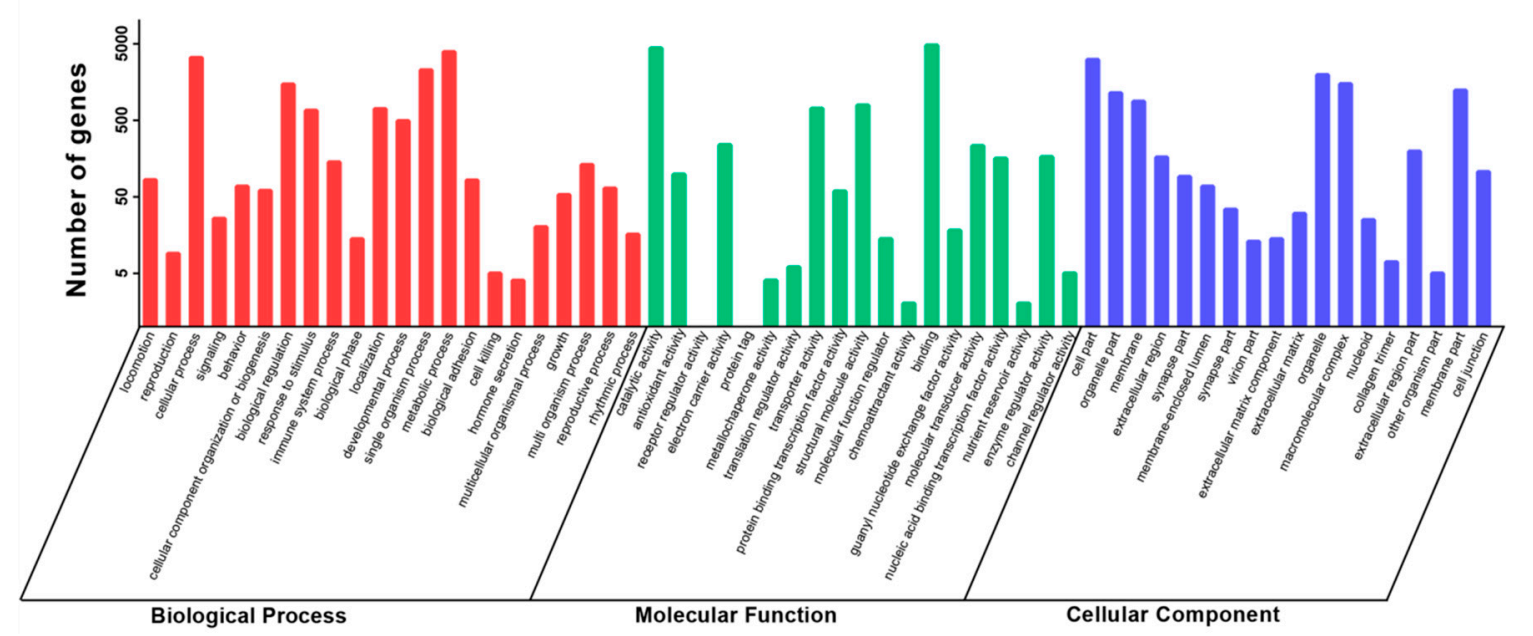

Figure 1. Gene Ontology (GO) classifications of unigenes. The $y$-axis represents the number of the unigenes, the $x$-axis shows three categories and their subcategories.

\subsection{Neuropeptide and Peptide Hormone Genes}

Based on Nr-annotation and homology searches, 40 genes encoding neuropeptides and neurohormones were identified in D. citri (Table 1), including the neuropeptides involved in physiology and behavior, such as allatotropin (AT), crustacean cardioactive peptide (CCAP), CCHamide (CCH), ecdysis triggering hormone (ETH), eclosion hormone (EH), SIFamide (SIF), pigment-dispersing factor (PDF), tachykinin (TK) and natalisin (NTL). Elevenin-like peptide (ELP) is a molluscan neuropeptide and was first identified in Aplysia californica, and later ELP was found in many insect species with the exception of D. melanogaster and B. mori, in D. citri, the gene coding for ELP was found. Prothoracicotropic hormone (PTTH) has been proposed to regulate development in insects, and it has been identified in D. citri, however, previously, in Hemipteran, PTTH was only identified in $N$. lugens. The adipokinetic hormone (AKH)/corazonin-related peptide (ACP), bursicon alpha subunit (Bur $\alpha$ ), FMRFamide (FMRF), glycoprotein hormone alpha 2 (GPA2), IMFamide (IMF), neuropeptide F (NPF), sulfakinin (SK), and trissin (TR) were not found in the transcriptome databases of D. citri (Supplementary Table S1).

Table 1. Neuropeptides identified from D. citri. ORF, open reading frame; SP, signal peptide; aa, amino acid.

\begin{tabular}{cccccccc}
\hline Neuropeptide Name & Accession No. & Acronym & ORF (aa) & SP (aa) & \multicolumn{3}{c}{ Homology Search with Known Protein } \\
\cline { 7 - 9 } & & & & Species & Protein ID & E-Value \\
\hline Adipokinetic hormone & MG550150 & AKH & 74 & 24 & $\begin{array}{c}\text { Nilaparvata } \\
\text { lugens } \\
\text { Rhodnius }\end{array}$ & AFN26934.1 & $6.00 \mathrm{e}-17$ \\
Allatostatin A & MG550151 & AstA & 181 & 21 & $\begin{array}{c}\text { prolixus } \\
\text { ACX47066.1 }\end{array}$ & $2.00 \mathrm{e}-21$ \\
Allatostatin B & MG550152 & AstB & 218 & 22 & $\begin{array}{c}\text { Plautia stali } \\
\text { Pseudomyrmex }\end{array}$ & BAU88428.1 & $2.00 \mathrm{e}-34$ \\
Allatostatin C & MG550153 & AstC & 98 & 23 & $\begin{array}{c}\text { gracilis } \\
\text { Pllautia stali }\end{array}$ & BAV787961.1 & $6.00 \mathrm{e}-27$ \\
\hline
\end{tabular}


Table 1. Cont.

\begin{tabular}{|c|c|c|c|c|c|c|c|}
\hline \multirow{2}{*}{ Neuropeptide Name } & \multirow{2}{*}{ Accession No. } & \multirow{2}{*}{ Acronym } & \multirow{2}{*}{ ORF (aa) } & \multirow{2}{*}{ SP (aa) } & \multicolumn{3}{|c|}{ Homology Search with Known Protein } \\
\hline & & & & & Species & Protein ID & E-Value \\
\hline Allatotropin & MG550155 & AT & 152 & 28 & $\begin{array}{l}\text { Nilaparvata } \\
\text { lugens }\end{array}$ & BAO00936.1 & $1.00 \mathrm{e}-08$ \\
\hline $\begin{array}{c}\text { Arginine } \\
\text { vasopressin-like } \\
\text { peptide }\end{array}$ & MG550156 & AVLP & 170 & 21 & $\begin{array}{l}\text { Nilaparvata } \\
\text { lugens }\end{array}$ & BAO00934.1 & $1.00 \mathrm{e}-04$ \\
\hline Bursicon beta subunit & MG550157 & Bur $\beta$ & 134 & 19 & $\begin{array}{l}\text { Nilaparvata } \\
\text { lugens }\end{array}$ & BAO00938.1 & $5.90 \mathrm{e}-52$ \\
\hline $\begin{array}{c}\text { Cardio acceleratory } \\
\text { peptide } 2 \mathrm{~b} / \text { Pyrokinin } 1\end{array}$ & MG550158 & $\mathrm{CAP} 2 \mathrm{~b}$ & 189 & 29 & $\begin{array}{l}\text { Nilaparvata } \\
\text { lugens }\end{array}$ & BAO00941.1 & $1.00 \mathrm{e}-13$ \\
\hline CCHamide 1 & MG550159 & $\mathrm{CCH} 1$ & 165 & 26 & $\begin{array}{l}\text { Nilaparvata } \\
\text { lugens }\end{array}$ & BAO00942.1 & $8.00 \mathrm{e}-13$ \\
\hline CCHamide 2 & MG550160 & $\mathrm{CCH} 2$ & 169 & 28 & Bombyx mori & BAG55002.1 & $6.00 \mathrm{e}-08$ \\
\hline CNMamide & MG550161 & CNM & 165 & 20 & Plautia stali & BAV78799.1 & $9.00 \mathrm{e}-07$ \\
\hline Corazonin & MG550162 & $\mathrm{Crz}$ & 155 & 26 & $\begin{array}{l}\text { Solenopsis } \\
\text { invicta }\end{array}$ & XP_011172976.1 & $2.00 \mathrm{e}-03$ \\
\hline $\begin{array}{c}\text { Crustacean cardioactive } \\
\text { peptide } \\
\text { Pyrokinin }\end{array}$ & MG550163 & CCAP & 149 & 25 & Plautia stali & BAV78802.1 & $4.00 \mathrm{e}-42$ \\
\hline $\begin{array}{l}\text { 2/Pheromone } \\
\text { biosynthesis activating } \\
\text { neruopeptide }\end{array}$ & MG550164 & PBAN & 200 & 29 & Bemisia tabaci & XP_018895833.1 & $5.00 \mathrm{e}-20$ \\
\hline Diuretic hormone 31 & MG550165 & DH31 & 119 & 29 & $\begin{array}{l}\text { Nilaparvata } \\
\text { lugens }\end{array}$ & BAO00939.1 & $2.00 \mathrm{e}-35$ \\
\hline $\begin{array}{c}\text { Diuretic hormone } \\
45 / \text { splicing variant of } \\
\text { CRF-DH }\end{array}$ & MG550166 & DH45 & 246 & 24 & $\begin{array}{l}\text { Nilaparvata } \\
\text { lugens }\end{array}$ & BAO00945.1 & $6.00 \mathrm{e}-15$ \\
\hline Eclosion hormone 1 & MG550167 & EH1 & 80 & 25 & Diuraphis noxia & XP_015365040.1 & $1.00 \mathrm{e}-34$ \\
\hline Eclosion hormone 2 & MG550168 & $\mathrm{EH} 2$ & 84 & 28 & $\begin{array}{l}\text { Nilaparvata } \\
\text { lugens }\end{array}$ & BAO00951.1 & $2.00 \mathrm{e}-19$ \\
\hline $\begin{array}{l}\text { Ecdysis triggering } \\
\text { hormone }\end{array}$ & MG550169 & ETH & 152 & 20 & Plautia stali & BAV78804.1 & $2.00 \mathrm{e}-06$ \\
\hline Elevenin-like peptide & MG550170 & ELP & 128 & 26 & $\begin{array}{l}\text { Nilaparvata } \\
\text { lugens }\end{array}$ & BAO00952.1 & $3.00 \mathrm{e}-06$ \\
\hline $\begin{array}{l}\text { Glycoprotein hormone } \\
\text { beta } 5\end{array}$ & MG550171 & GP $\beta 5$ & 138 & 18 & $\begin{array}{l}\text { Nilaparvata } \\
\text { lugens }\end{array}$ & BAO00956.1 & $3.00 \mathrm{e}-53$ \\
\hline ITG-containing peptide & MG550172 & ITG & 216 & 21 & $\begin{array}{c}\text { Agrilus } \\
\text { planipennis }\end{array}$ & XP_018325057.1 & $2.00 \mathrm{e}-81$ \\
\hline Insulin-like peptide 1 & MG550173 & ILP1 & 136 & 25 & $\begin{array}{l}\text { Nilaparvata } \\
\text { lugens }\end{array}$ & AIY24645.1 & $1.00 \mathrm{e}-03$ \\
\hline Insulin-like peptide 2 & MG550174 & ILP2 & 147 & 20 & $\begin{array}{l}\text { Nilaparvata } \\
\text { lugens }\end{array}$ & BAO00958.1 & $4.00 \mathrm{e}-04$ \\
\hline $\begin{array}{c}\text { Ion transport peptide } \\
\text { like }\end{array}$ & MG550175 & ITPL & 124 & 26 & $\begin{array}{l}\text { Harpegnathos } \\
\text { saltator }\end{array}$ & XP_011137372.1 & $2.00 \mathrm{e}-51$ \\
\hline Kinin & MG550176 & Kin & 327 & 28 & Plautia stali & BAV78814.1 & $6.00 \mathrm{e}-17$ \\
\hline Myosuppressin & MG550177 & MS & 100 & 22 & $\begin{array}{l}\text { Nilaparvata } \\
\text { lugens }\end{array}$ & BAO00963.1 & $6.00 \mathrm{e}-32$ \\
\hline Natalisin & MG550178 & NTL & 214 & 25 & $\begin{array}{c}\text { Chilo } \\
\text { suppressalis }\end{array}$ & ALM30330.1 & $8.70 \mathrm{e}-02$ \\
\hline Neuroparsin & MG550179 & NP & 96 & 19 & Bombyx mori & BAG50366.1 & $1.00 \mathrm{e}-13$ \\
\hline $\begin{array}{l}\text { Neuropeptide-like } \\
\text { precursor } 1\end{array}$ & MG550180 & NPLP1 & 617 & 19 & $\begin{array}{l}\text { Nilaparvata } \\
\text { lugens }\end{array}$ & BAO00966.1 & $3.00 \mathrm{e}-05$ \\
\hline $\begin{array}{l}\text { neuropeptide-like } \\
\text { precursor } 3\end{array}$ & MG550181 & NPLP3 & 83 & 16 & $\begin{array}{l}\text { Anoplophora } \\
\text { glabripennis }\end{array}$ & XP_018572912.1 & $7.00 \mathrm{e}-03$ \\
\hline Orcokinin & MG550182 & OK & 164 & 17 & $\begin{array}{l}\text { Nilaparvata } \\
\text { lugens }\end{array}$ & BAO00969.1 & $2.00 \mathrm{e}-30$ \\
\hline $\begin{array}{l}\text { Pigment dispersing } \\
\text { factor }\end{array}$ & MG550183 & PDF & 82 & 25 & $\begin{array}{l}\text { Nilaparvata } \\
\text { lugens }\end{array}$ & BAO00970.1 & $1.00 \mathrm{e}-07$ \\
\hline Proctolin & MG550184 & Pro & 72 & 28 & $\begin{array}{l}\text { Nilaparvata } \\
\text { lugens }\end{array}$ & BAO00972.1 & $1.20 \mathrm{e}-02$ \\
\hline $\begin{array}{l}\text { Prothoracicotropic } \\
\text { hormone }\end{array}$ & MG550185 & PTTH & 168 & 31 & $\begin{array}{l}\text { Nilaparvata } \\
\text { lugens }\end{array}$ & BAO00973.1 & $1.00 \mathrm{e}-09$ \\
\hline RYamide & MG550186 & RY & 165 & 24 & $\begin{array}{c}\text { Chilo } \\
\text { suppressalis }\end{array}$ & ALM30346.1 & $1.80 \mathrm{e}-02$ \\
\hline Short neuropeptide F & MG550187 & sNPF & 110 & 27 & $\begin{array}{l}\text { Nilaparvata } \\
\text { lugens }\end{array}$ & BAO00976.1 & $2.00 \mathrm{e}-17$ \\
\hline SIFamide & MG550188 & SIF & 75 & 22 & $\begin{array}{l}\text { Tribolium } \\
\text { castaneum }\end{array}$ & EFA07409.1 & $3.00 \mathrm{e}-17$ \\
\hline Tachykinin & MG550189 & TK & 199 & 20 & $\begin{array}{l}\text { Tribolium } \\
\text { castaneum }\end{array}$ & KYB25859.1 & $3.00 \mathrm{e}-14$ \\
\hline
\end{tabular}




\subsection{G-Protein-Coupled Receptors (GPCRs) for Neuropeptides}

A total of 42 putative neuropeptide GPCRs genes were identified in the transcriptomes of $D$. citri based on homology analysis (Table 2). Of these receptors, 35 GPCRs belong to the A family, four belong to B family, and three belong to leucine-rich repeat-containing GPCRs (LGRs). In order to assign putative functions of these GPCRs, we compared them with those of D. melanogaster, N. lugens, and other arthropods. The results are presented as a neighbor-joining tree in Figures 2-4.

Table 2. Neuropeptide G-protein-coupled receptor (GPCR) genes identified from D. citri. ORF, open reading frame; aa, amino acid; TMDs, transmembrane domains.

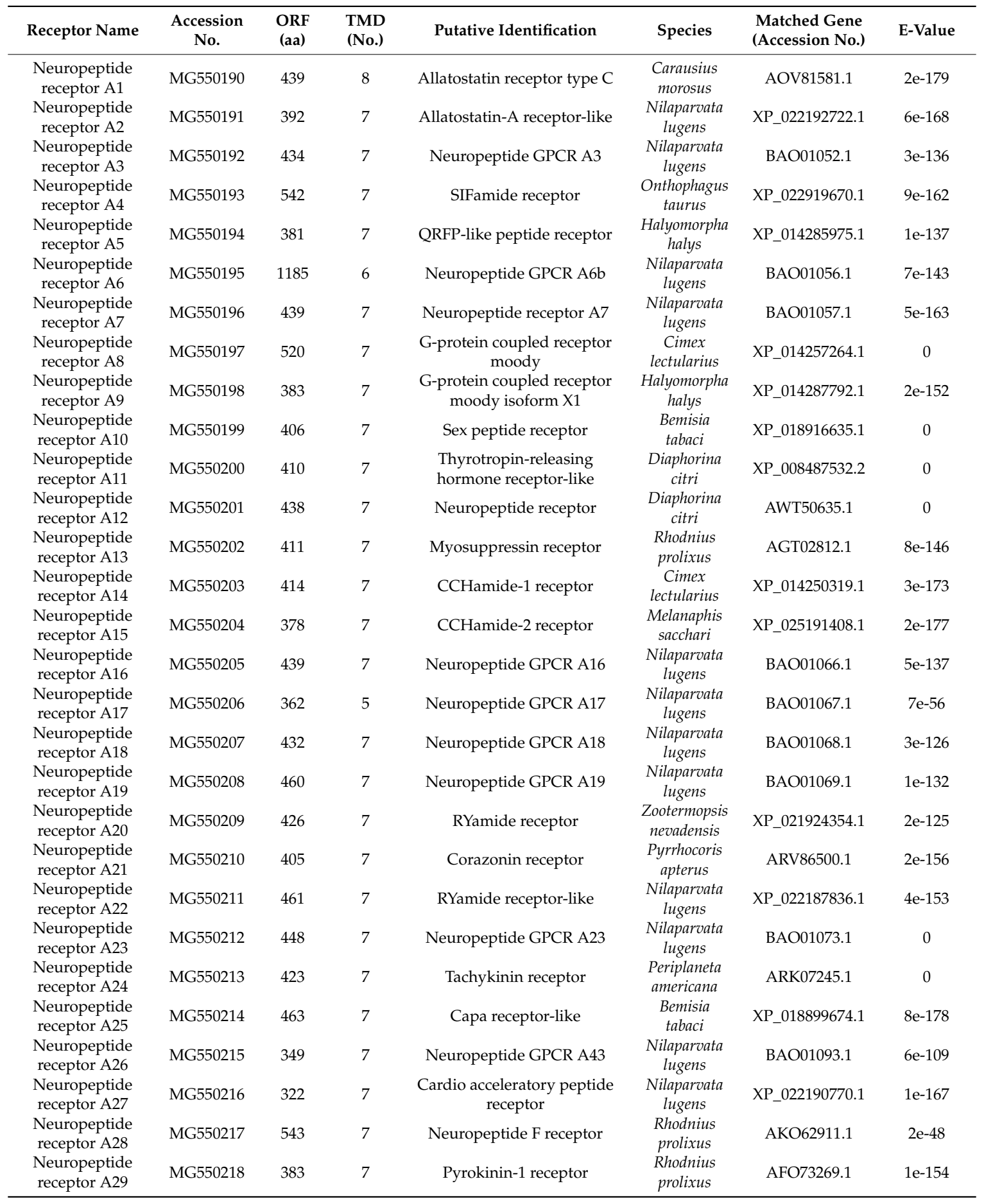


Table 2. Cont.

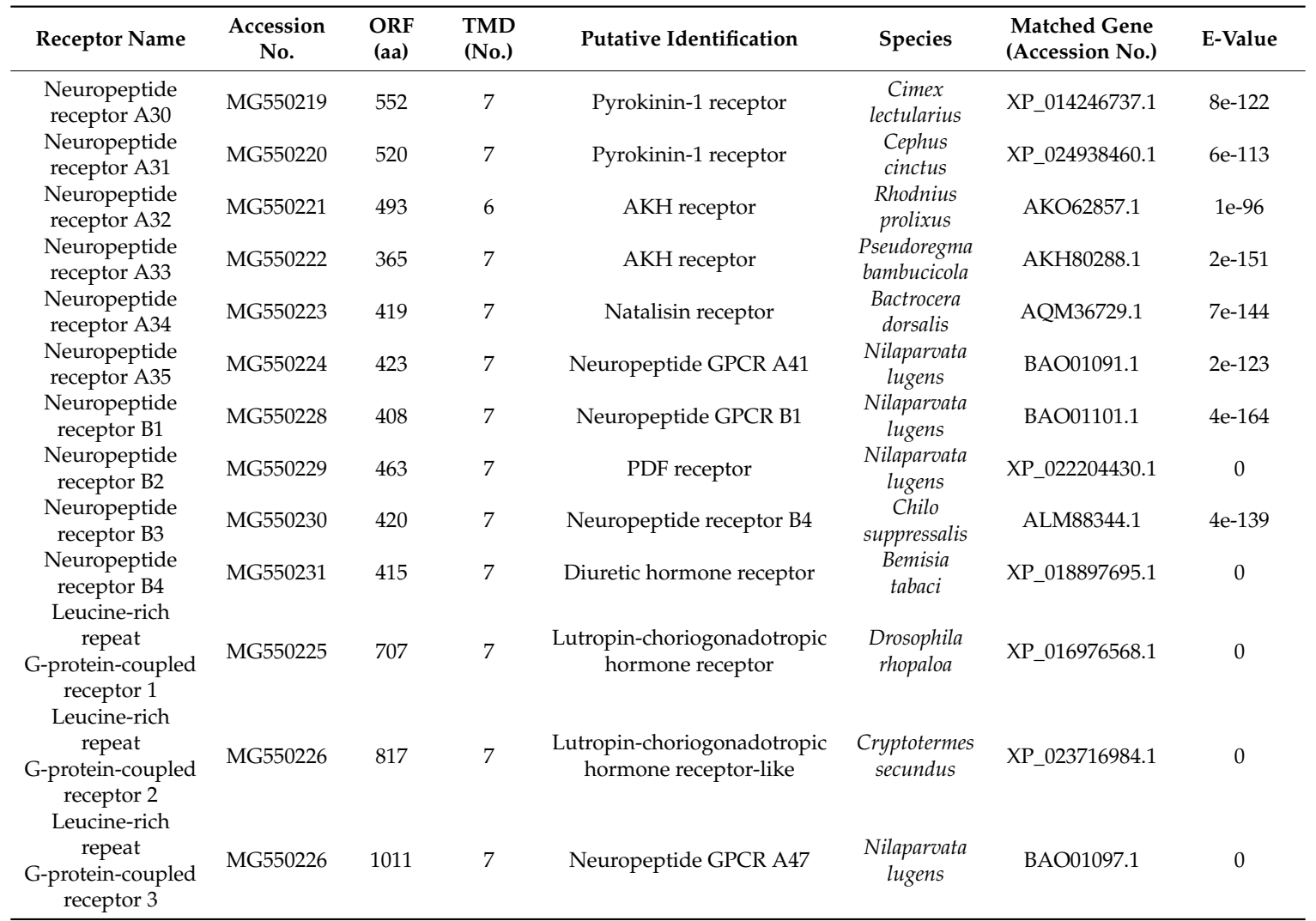

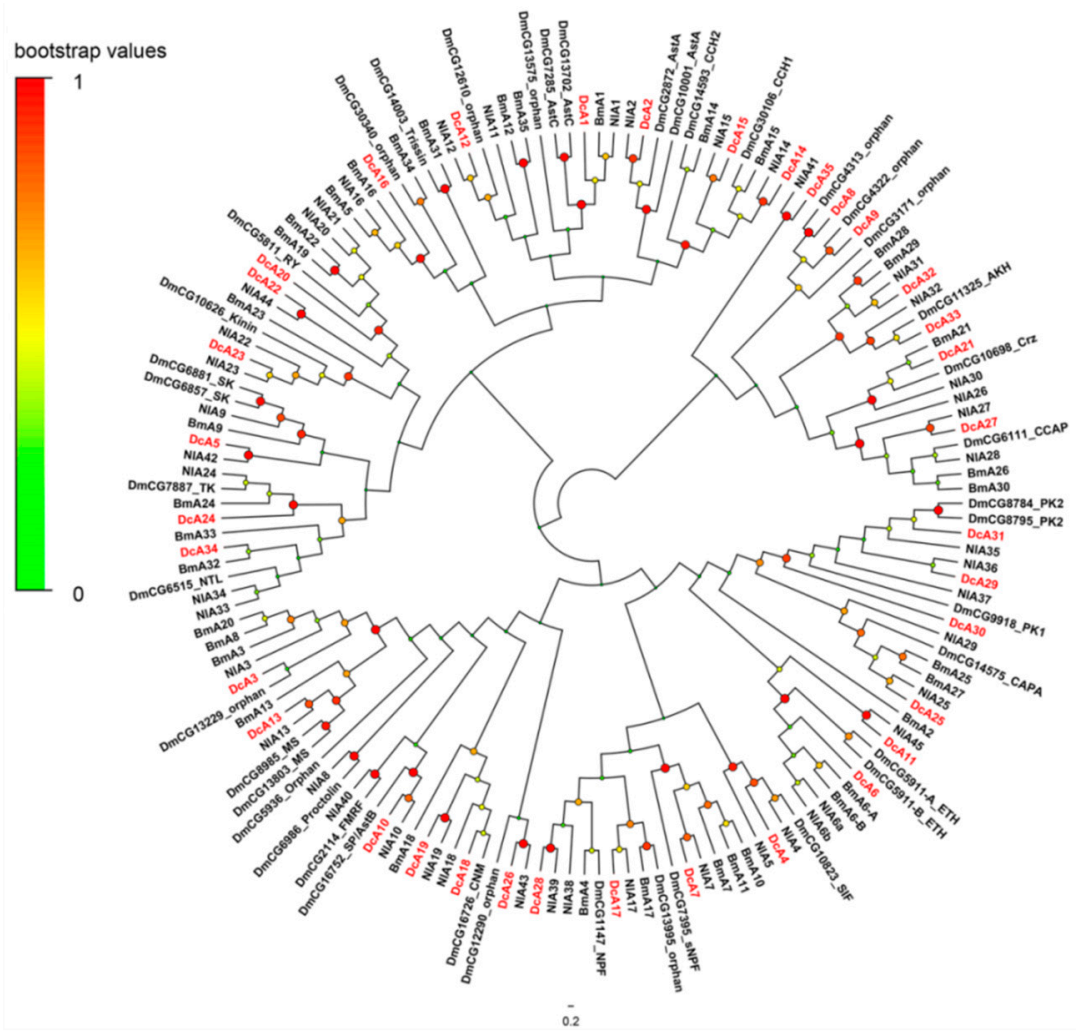

Figure 2. Phylogenetic tree of the A-family neuropeptide GPCRs. The neighbor-joining trees were constructed using MEGA 6 software with 1000-fold bootstrap repetitions. The A-family neuropeptide GPCRs of D. citri are shown in red text. Dc, D. citri; Dm, D. melanogaster; $\mathrm{Nl}, \mathrm{N}$. lugens. 


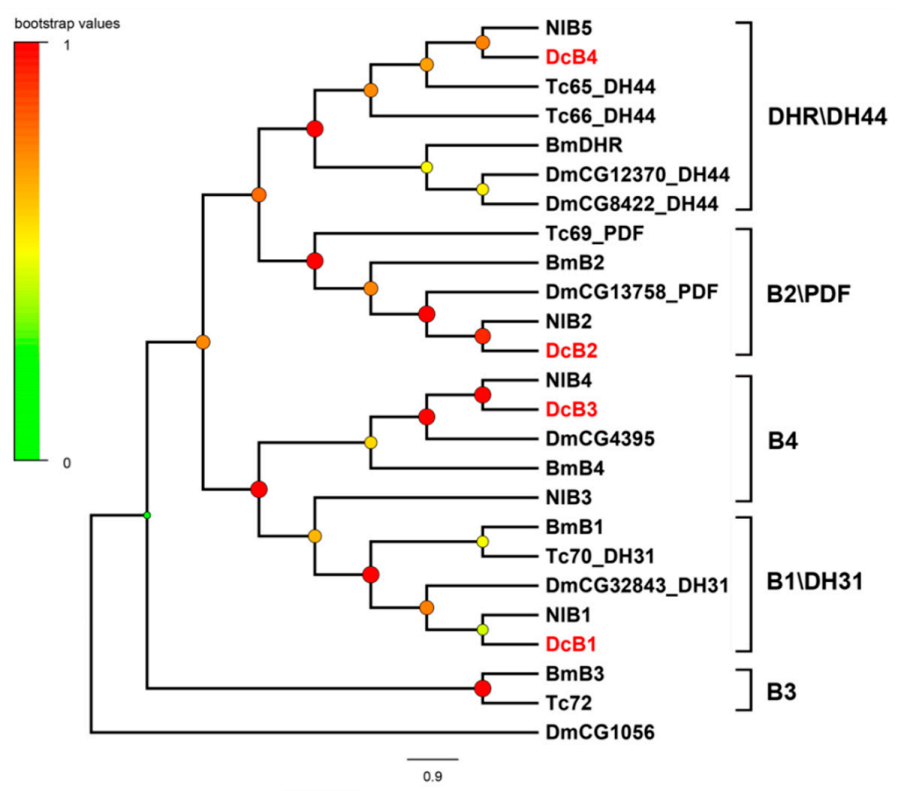

Figure 3. Phylogenetic tree of the B-family neuropeptide GPCRs. The neighbor-joining trees were constructed using MEGA 6 software with 1000-fold bootstrap repetitions. The B-family neuropeptide GPCRs of D. citri are shown in red text. Dc, D. citri; Dm, D. melanogaster; Nl, N. lugens; Bm, B. mori; Tc, T. castaneum.

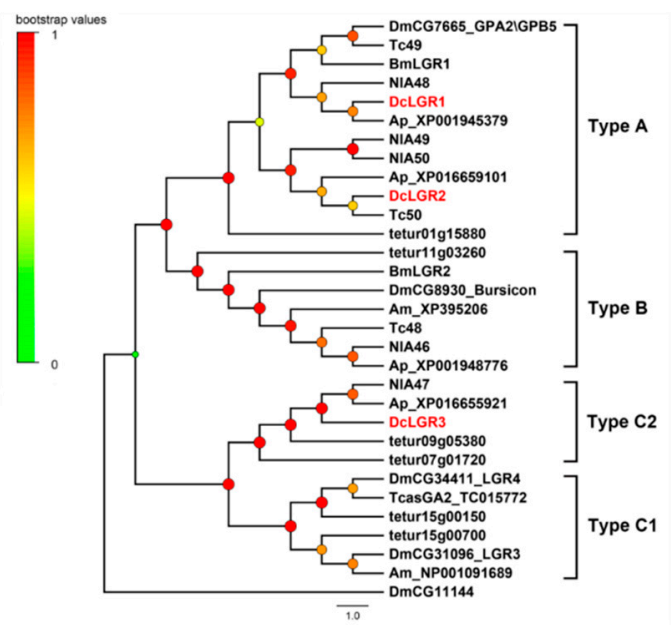

Figure 4. Phylogenetic tree of leucine-rich repeat-containing GPCRs (LGRs). The neighbor-joining trees were constructed using MEGA 6 software with 1000-fold bootstrap repetitions. The LGRs of $D$. citri are shown in red text. Dc, D. citri; Dm, D. melanogaster; Nl, N. lugens; Bm, B. mori; Tc, T. castaneum. Ap, Acyrthosiphon pisum; Am, A. mellifera; tetur, Tetranychus urticae.

\subsubsection{A-Family GPCRs}

The A-family GPCRs are also known as the rhodopsin family. Thirty-five A-family neuropeptide GPCRs were identified in D. citri. In the phylogenetic tree of A-family GPCRs (Figure 2), DcA5, DcA20, DcA22-24, and DcA34 were clustered in a clade with DmCG5811 (RYamide receptor, RYR), DmCG10626 (Kinin receptor, KinR), DmCG6857 (Sulfakinin-like receptor, SKR), DmCG6881 (Sulfakinin-like receptor, SKR), CG7887 (Tachykinin receptor, TKR), DmCG6515 (Natalisin receptor, NTLR). DcA5, DcA23, DcA24, and DcA34 were identified as SKR, KinR, TKR, and NTLR respectively. DcA22 and DcA20 are two orthologs of DmRYaR. DcA7, DcA17, and DcA28 stay in the clade of NPF and short Neuropeptide $\mathrm{F}$ (sNPF) receptors, DcA28 is the receptor of NPF (NPFR), and DcA7 and DcA17 were identified as sNPF receptors (sNPFR). Besides that, there is another big clade locating in the phylogenetic tree, and it contains the Pyrokinin receptor (PKR), cardio acceleratory peptide (CAPAR), ecdysis-triggering 
hormone receptor (ETHR). DcA6 was predicted as ETHR, and DcA25 acts as a CAPAR, based on the Blastp analysis and phylogenetic analysis. DcA25 and DcA30 were identified as PK1R, DcA31 was identified as PK2R. The receptors of the GnRH-related peptides and CCAP were clustered in a clade, including DcA21, DcA27, DcA32, and DcA33. DcA21 located in the subtree of the corazonin receptor with BmA21, DcA27 was identified as CCAPR. DcA32 and DcA33 act as the receptor of AKH. DcA8, DcA9, and DcA35 are paralogs of CCAPR and AKHR; however, DcA8 and DcA9 are similar to two orphan receptors, DmCG4313 and DmCG4322. DcA35 is similar to N1A41, and NlA41 is an ortholog of the receptor for AVLP of T. castaneum, further based on blastp analysis, DcA35 has a high homology with AVLPR of T. castaneum (ABX00684, e-value 3e-112). As above, DcA35 was characterized as DcAVLPR. DcA11 is an ortholog of NlA45, and NlA45 is remarkably similar to the vertebrate thyrotropin-releasing hormone receptors (TRHRs). The receptors for CNMamide (CNM), FMRF, Myosuppressin (MS), sex peptide (SP), Proctolin (Pro), and 3 orphan receptors, DmCG12290, DmCG5986, and DmCG13229 were clustered in a clade. This clade included DcA3, DcA10, and DcA13. DcA10 was identified as the receptor of SP (SPR), and DcA13 acts as MS receptor (MSR). The predicted function of DcA3 was not identified. At last, DcA1, DcA2, DcA4, and DcA15 were obviously identified as receptors of AstC, AstA, SIF, and $\mathrm{CCH}$, respectively.

\subsubsection{B-Family GPCRs}

B-family GPCRs contain three subfamilies: subfamily B1, subfamily B2, and subfamily B3. Here the B-family neuropeptide GPCRs belong to the subfamily B1. Four B-family GPCRs associated with neuropeptide recognition were confirmed in D. citri. Each amino acid sequence of these candidate receptors contains the characteristic hormone receptor domain. In the phylogenetic tree of B-family GPCRs (Figure 3), four receptors were classified into four branches. DcB1 and DcB4 were identified as receptors of DH31 and DH44. DcB1 is the ortholog of DmCG32843, and DcB4 is the ortholog of CG12370 and DmCG8422. DcB2 was annotated as the receptor of PDF, which is involved in prolonging mating duration. DcB3 is an ortholog of DmCG4395, and it shows high similarity to the calcitonin-like diuretic hormone receptor 2 of $R$. prolixus (AHB86571, e-value 0.0).

\subsubsection{Leucine-Rich Repeat-Containing GPCRs (LGRs)}

Leucine-rich repeat-containing GPCRs are a class of GPCRs containing leucine-rich repeats (LRRs) at the $\mathrm{N}$-terminus. Based on the number of LRRs, the type-specific hinge region and the presence or absence of a low-density lipoprotein receptor-like cysteine-rich motif (LDLa), LGRs can be identified as three main types (type A, B, and C). Furthermore, according to the number of LDLa motifs, Type C LGRs can be divided into two subtypes: Type C1, which contain only one LDLa, and Type C2, which contain multiple LDLa motifs. Three LGRs were identified in D. citri, two belong to Type A and one belong to Type C2. Both DcLGR1 and DcLGR2 contain eight LRRs, and this is a typical feature of Type A. In the phylogenetic tree of leucine-rich repeat-containing GPCRs (Figure 4), DcLGR1 and DcLGR2 are homologous to DmCG7665 which is the receptor of glycoprotein hormones in Drosophila. DcLGR3 contains eight LDLa motifs and two LRRs, and it belongs to Type C2. DcLGR3 is an ortholog of NlA47 which is also known as NIGRL101.

\subsection{Tissue-Specific Expression Profiles of the Neuropeptides and Neuropeptide Receptors}

In order to understand the potential function of the neuropeptides and neuropeptide receptors in D. citri, the expressions of the neuropeptides and neuropeptide receptors were profiled for different tissues of D. citri based on the transcriptome data (Figure 5). AKH, DH31, SIF, AstB, CCH2, ILP, EH2, CNM, ELP, CCAP, and Kin are ubiquitous in the tissues of the female and male adult. AstA-C, TK, CAPA, ITG, CCH1-2, MS, sNPF, OKA, ILP1-2, SIF, NTL, EH2, AVLP, PBAN, NPLP1, and CNM show high expression levels in head, and AstA, CAPA, ITG, IPL2, NTL; PDF express in head and antenna; CNM also shows the highest expression level in legs of all tissues; and ELP and CCAP have a high expression level in abdomen terminal. 


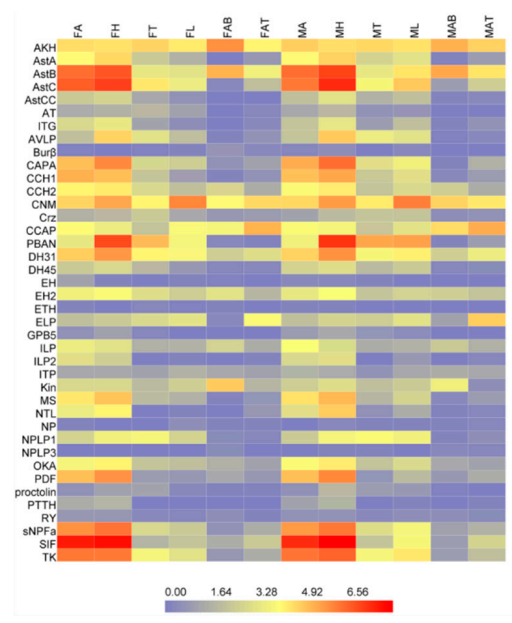

Figure 5. Expression profiles of neuropeptides in various tissues of D. citri based on FPKM values (fragments per kilobase per million reads). The mRNA levels, as represented by log2 (FPKM +1 ) values, are shown in a heat map with colors ranging from blue (low expression) to red (high expression). MA, male antenna; MH, male head; MT, male thorax; ML, male leg; MAB, male abdomen; MAT, male abdomen terminal; FA, female antenna; FH, female head; FT, female thorax; FL, female leg; FAB, female abdomen; FAT, female abdomen terminal.

The overwhelming majority of the neuropeptide receptors appear to be lowly expressed in all tissues in addition to A4, A7, A9, A12, A18, A23, A26, A27, A31, A33, B2, LGR1 (Figure 6). LGR1 (glycoprotein hormones), A26, A27 (CCAP) have the highest expression levels of all the receptors and exist in all tissues of the female and male adult. A7 (sNPF), A9, A25 (CAPA), and A31 (PBAN) express broadly in the head, thorax, and abdomen except the abdomen terminal. A4 (SIF), A12, and B2 (PDF) express mainly in the head and antenna. A23 (kinin) show the specific expression in the abdomen of female and male. A18 (CNM) especially expresses in the abdomen and abdomen terminal of the male. A24 (TK) have higher expressions in the head and antenna of males than other tissues.

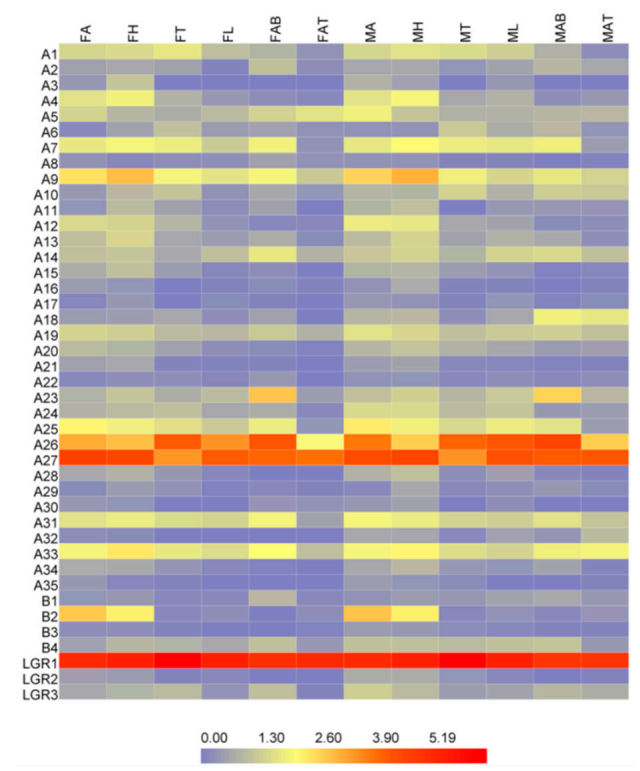

Figure 6. Expression profiles of neuropeptide receptors in various tissues of D. citri based on FPKM values. The mRNA levels, as represented by $\log 2($ FPKM +1$)$ values, are shown in the heat map with colors ranging from blue (low expression) to red (high expression). MA, male antenna; $\mathrm{MH}$, male head; MT, male thorax; ML, male leg; MAB, male abdomen; MAT, male abdomen terminal; FA, female antenna; FH, female head; FT, female thorax; FL, female leg; FAB, female abdomen; FAT, female abdomen terminal. 


\subsection{Developmental Stages Expression Analysis by RT-qPCR}

Developmental stages expression profiles of the neuropeptides and neuropeptide receptors were confirmed by the RT-qPCR (Figures 7 and 8). AKH, AVLP, Bur $\beta$, DH31, DH45, PBAN, and OK had the highest expressional level in the 1st and 2nd instar nymphs. AstB, AstC, CAP2b, CCH1, CNM, GPb5, MS, and TK showed the highest expression of the adults at five days after eclosion (sexual maturity). The expression level of Kin, NP, and PTTH decreased gradually from egg to sexual maturity. The neuropeptide receptors A3, A5, A12, A13, A16, A18, A21-24, A28-A30, A32, A34, B1, B3, and LGR3 were predominately expressed in egg, and A14, A25-27, and B4 mainly expressed in adults. A35 and two orphan receptors (A9 and A17) both expressed highly in egg and adult.

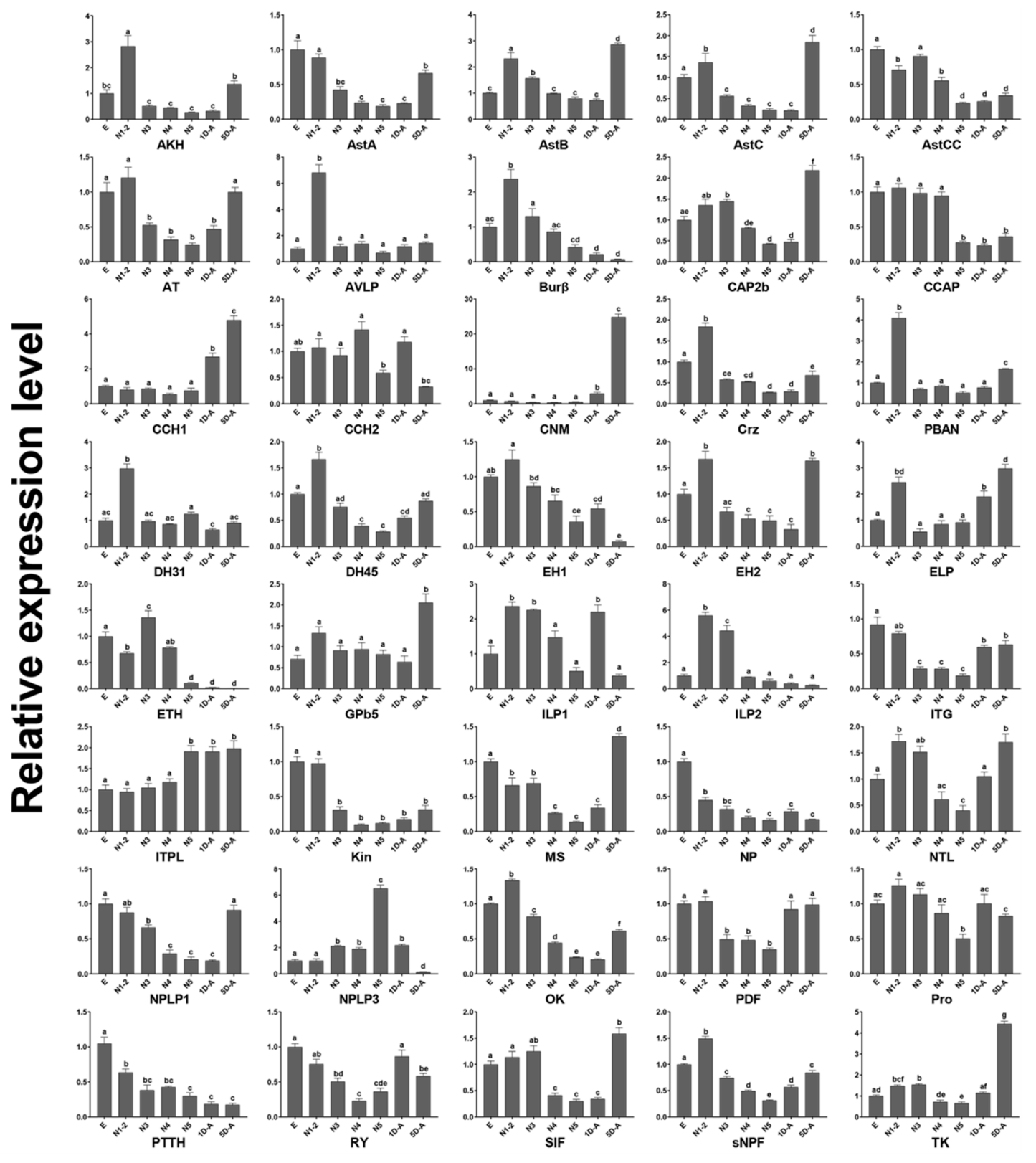

Figure 7. qRT-PCR results of neuropeptides throughout the D. citri life cycle. The $y$-axis represents the relative expression level and the $x$-axis the life cycle. The standard error is represented by the error bar and significant differences are represented by the different letters $(p<0.05)$. E, egg; N1-2, 1stand 2nd-instar nymphs; N3, 3rd instar nymphs; N4, 4th instar nymphs; N5, 5th instar nymphs; 1D-A, the adults of one day after eclosion; 5D-A, five days after eclosion. 


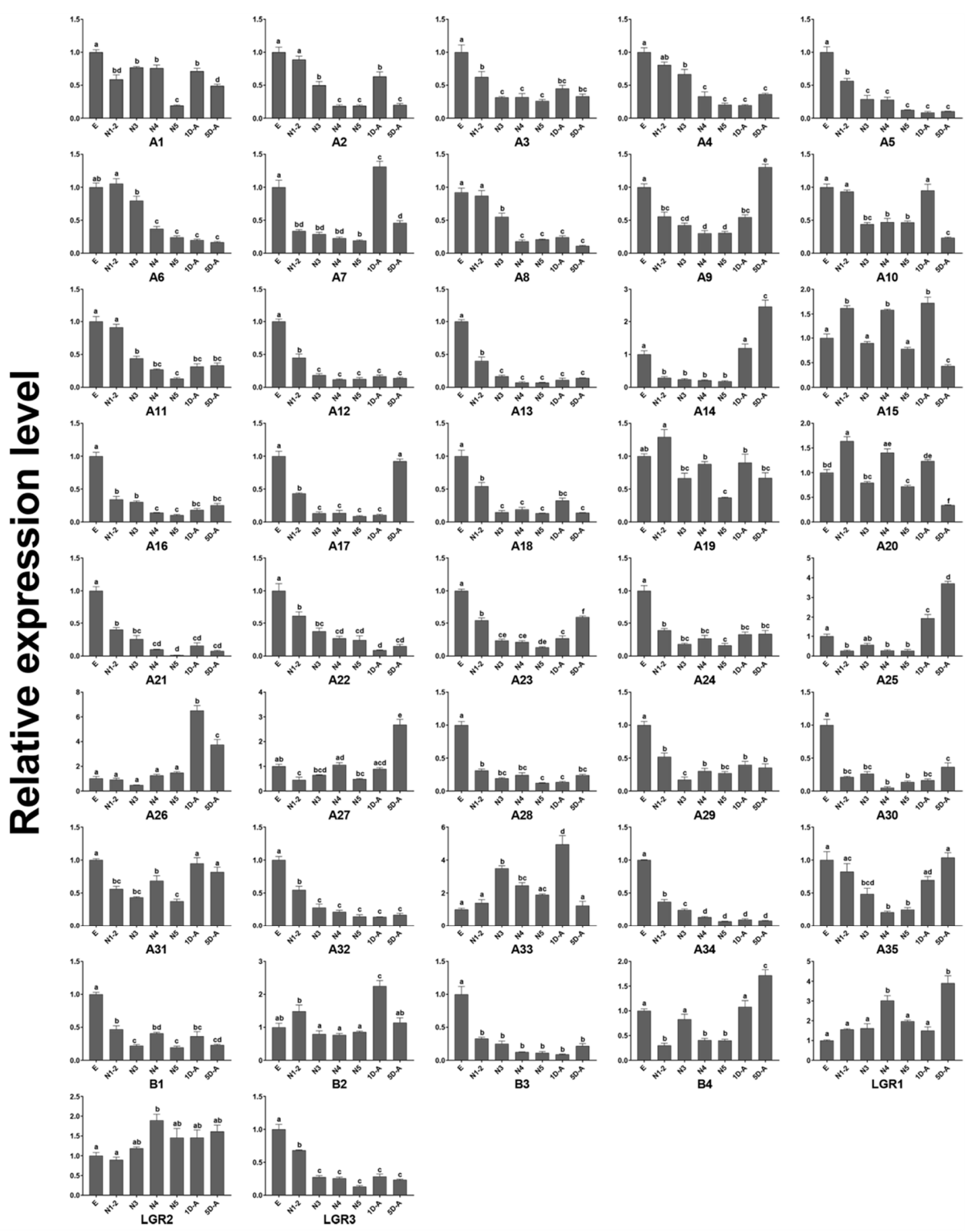

Figure 8. The gene expression level of neuropeptide receptors throughout the D. citri life cycle. The $y$-axis represents the relative expression level and the $x$-axis the life cycle. The standard error is represented by the error bar and significant differences are represented by the different letters $(p<0.05)$. E, egg; N1-2, 1st- and 2nd-instar nymphs; N3, 3rd instar nymphs; N4, 4th instar nymphs; N5, 5th instar nymphs; 1D-A, the adults of one day after eclosion; 5D-A, five days after eclosion.

\section{Discussion}

Control of D. citri is the key component of integrated control for citrus Huanglongbing. However, effective control measures are not currently available. As potential pesticides and new targets emerge on account of continuing development of existing insecticide resistance [1,25], the primary task of developing neuroendocrine-based insecticides is to identify the structure and function of neuropeptides 
and receptors, especially those involved in survival, development, and/or reproduction [11]. However, the molecular basis of the behavior of $D$. citri is poorly understood. Besides, the lack of genomic information prevents us from understanding the regulatory network of the neuropeptides. Fortunately, transcriptome analysis has provided the methods to identify and characterize multiple genes in insects [23], and using RNA-seq a number of genes encoding neuropeptides and their receptors were identified from $D$. citri.

The present transcriptional sequences of $D$. citri appear to contain most of the genes for insect neuropeptides and GPCRs except for several genes. Several neuropeptides (e.g., Trissin (TR) and IMFamide (IMF) orthologs) were also not identified in other Hemipteran insects such as A. pisum [26], $N$. lugens [23], and R. prolixus [11]. In fact, IMF is a unique neuropeptide of Lepidoptera and has not been found in other insects [20]. Neuropeptide F (NPF) is identified in almost all insect species and plays roles in feeding, metabolism, reproduction, and stress responses [20], whereas the BLAST search of transcriptomic data failed to find NPF in D. citri. Similarly, we have identified an ortholog of Proctolin; however, the receptor was not found. This may be due to the incomplete analyses of transcriptome information. Indeed, the gene coding for natalisin (NTL) and CNMamide (CNM) were identified from R. prolixus by reinvestigation [11] contrary to the previous suggestion that NTL and CNM were absent [24].

\subsection{Neuropeptides Involved in Ecdysis and Development}

Ecdysis-triggering hormone (ETH), eclosion hormone (EH), and crustacean cardioactive peptide (CCAP) are main players of the peptidergic circuit controlling ecdysis in insects. The functions of these peptides have been reported in the Drosophila and other insects $[27,28]$. In insects, EH is expressed in CNS, ETH production in endocrine cells in the epitracheal gland (Inka cells), and the CCAP-expressing neurons are located in abdominal ganglia [27]. Both ETH and EH regulate the release of CCAP from central CCAP neurons which inhibits pre-ecdysis [2]. In D. citri, one ETH encoding gene was identified, and two different genes encoding EH were identified. According to the expression profiles, ETH and EH1 show high expression levels in the nymph stage, and we can presume that ETH and EH1 play a vital role in molting processes.

Juvenile hormone $(\mathrm{JH})$ is an important hormone and regulates development and growth in insects. Traditionally JH production in the corpora allata has been considered to be controlled by the peptides Allatotropins (AT) [29] and Allatostatins (Ast) [2]. The first insect AT was isolated from head extracts of Manduca sexta. This peptide was shown to stimulate JH biosynthesis by the corpora allata (CA) of adult females [29]. Allatostatins are diverse peptides derived from three different genes in insects, which were designated as Ast $\mathrm{A}, \mathrm{Ast} \mathrm{B}$, and AstC. These peptides act as the inhibitors of $\mathrm{JH}$ production in corpora allata (CA) and have antagonism to AT [30]. Feeding the Lepidopteran AstC led to reduced growth and fecundity and caused significant mortality in A. pisum and in Myzus persicae [31,32]. The function of AstC receptors has been characterized in A. aegypti and T. castaneum, and they express in the central nervous system and gut [33,34]. Besides that, AstCC is a Type-C Ast and shows strong similarities to AstC. AstCC also has the function to regulate the biosynthesis of JH [35]. In D. citri, from 3rd instar nymphs to sexual maturity, the expression of AstCC shows a decreasing trend, and AT shows a growth trend. This result suggests that AT and AstCC might be involved in the regulation of $\mathrm{JH}$ production in D. citri.

\subsection{Neuropeptides Control of Metabolism}

Insulin-like peptides (ILPs) widely exist in insects and the insulin-like signaling pathway is conserved across higher multicellular animals [36]. In Drosophila, ablation of the insulin-producing cells, or deactivation of the ILPR leads to a series of phenotypes including grow logy, increased starvation resistance, increased levels of circulating carbohydrates cycling, elevated lipid storage, and lifespan extension [2]. Adipokinetic hormone (AKH) is suggested to be similar to mammalian glucagon and acts antagonistically to insulin by activating glycogen phosphorylase and mobilizing 
carbohydrates [37]. When the AKH-producing neuroendocrine cells were ablated in Drosophila, the trehalose levels of larvae and starved adults decreased, and these adults without AKH-cells become hypoactive, suggesting that $\mathrm{AKH}$ is involved in maintaining normal levels of circulating carbohydrates [38]. Ectopic expression of AKH in the fat body resulted in both increased circulating trehalose and a decrease in stored lipids [2]. In D. citri, two genes encoding ILP1 and ILP2 and one gene encoding AKH were identified, and more research is needed to reveal the functions of these genes.

The insect kinins are multifunctional neuropeptides shown to modulate hindgut contractions [39,40], diuretic activity [41,42], digestive enzyme release [40,43], and inhibit weight gain in larvae Lepidoptera $[43,44]$. Feeding the analogs of kinin to the pea aphid demonstrated that three of the biostable analogs showed antifeedant activity [45]. In D. citri, we identified one kinin precursor and one kinin receptor (DcA23), the kinin and the kinin receptor both express in the abdomens (Figures 5 and 6). On the present understanding of the expression profile of Kin and the receptor, we speculate that kinin and DcA23 may be involved in regulating the digestion process in D. citri and they represent a potential pesticide and target.

\subsection{Reproductive-Related Neuropeptides}

SIFamide (SIF) is strictly conserved and widespread in insects and modulates sexual behavior, and it was first found in 1995 in HPLC (high-performance liquid chromatography) fractions [46]. In Drosophila, the expression of SIF was restricted to only four neurons of the pars intercerebralis, when the SIF neurons was ablated, the lacking SIF-less males perform vigorous and indiscriminate courtship directed at either sex, while females appear sexually hyper-receptive. When the SIF gene was knocked down via RNAi, the decrease of SIF also led to a similar change of behavior [47]. SIFamides show a conserved sequence, X1-X2-RKPPFNGSIFamide, and the SIFs differ only in their N-terminal amino [46], in D. citri, SIF and the receptor of SIF (DcA4) were detected.

Neuropeptide pigment-dispersing factor (PDF) is involved in maintaining behavioral rhythms in D. melanogaster [48]. In addition, males usually prolong mating duration in the presence of other males to increase the chance of successful gene transfer, this effect in D. melanogaster requires both Neuropeptide F receptor 1 (NPFR1) and PDF expressing in four small ventrolateral neurons as well as the PDF receptor and expressing Neuropeptide F (NPF) in two dorsolateral neurons [49]. Apparently, PDF and NPF work together to regulate prolonged mating duration in D. melanogaster. In this study, PDF was identified in D. citri; however, NPF was not found.

Natalisin (NTL) is an arthropod-specific neuropeptide which was recently identified in three holometabolous insect species: D. melanogaster, T. castaneum, and B. mori, and was proven to be involved in regulating mating behavior in D. melanogaster and T. castaneum [50]. The latest research on NTL shows that NTL is involved in modulating the mating of the oriental fruit fly, Bactrocera dorsalis [51]. The NTL precursors generally contain multiple repeats sequences of F-X1-X2-X3-Ra at the C-terminus. In hemipteran, $\mathrm{X} 1$, is usually $\mathrm{W}$, and $\mathrm{X} 2$ is $\mathrm{P}$ [52]. In D. citri, NTL precursors and the receptor of NTL (DcA34) was identified, according to the amino acid sequences of the NTL precursor, four mature peptides were predicted (Supplementary Figure S1). The conservatism of NTLs sequences implies the conservatism of the functions; NTL will be a worthwhile option in developing novel control methods against $D$. citri.

\subsection{Neuropeptides in Olfaction}

Tachykinin (TK) is a multifunctional peptide, and it has been identified in many vertebrate and invertebrate species. In all vertebrate and a few invertebrate the TKs share a common C-terminal sequence motif, F-X-G-L-Ra [53]. Tachykinin is important in odor-based searching behavior of fruit flies, and several olfactory neurons contain high TK levels [54]. In Drosophila, (3R,11Z,19Z)-3-acetoxy-11,19-octacosadien-1-ol (CH503) is a gustatory sex pheromone. CH503 is detected by gustatory neurons on the male foreleg, a cluster of $8-10$ neurons within the subesophageal region which mediates the pheromone response through the release of the TKs [55]. In D. citri, 
we identified four mature peptides of TK; all mature peptides have conserved sequences at the C-terminus (Supplementary Figure S1). Tachykinin shows a high expression level in antenna and DcA24 shows high expression in male antenna and head in D. citri, but beyond that, TK also showed the highest expression in adults at five days after sexual maturity. Based on the expression profile, it is probable that TK and DcA24 are involved in the recognition of the odor by adults. Therefore, TK and the receptor can be considered as a potential behavioral regulatory pesticide or target.

$\mathrm{CCH} 1$ and $\mathrm{CCH} 2$ were initially identified in the tsetse fly Glossina morsitans [56]. In Drosophila, $\mathrm{CCH} 1$ and $\mathrm{CCH} 2$ played a role in appetite regulation by activating their receptors respectively $[57,58]$. The receptor of $\mathrm{CCH} 1$ was also an important factor governing starvation-induced olfactory modifications [59]. Here, both CCH1 and CCH2 were identified in D. citri, and their corresponding receptors were excavated, $\mathrm{A} 14(\mathrm{CCH} 1)$ and $\mathrm{A} 15(\mathrm{CCH} 2)$, respectively. In D. citri, CCH1 and A14 presented high expression in adulthood, besides that, $\mathrm{CCH} 1$ is highly expressed in antennae and head. According to the results, it was assumed that $\mathrm{CCH} 1$ and A14 may play an important role in regulating starvation-induced host recognition behavior at the adult stage of $D$. citri. In addition to TK and CCHs, AstA, sNPF, and SIF also show high expression level in antenna and head, and it is consistent with neuropeptides expressed in brain and the antennal lobe of other insects as in previous reports $[47,60,61]$.

\section{Materials and Methods}

\subsection{Insect Rearing and RNA Extraction}

The insects were collected from the Murraya exotica in the campus of South China Agricultural University, Guangzhou, Guangdong Province, China in 2013. The laboratory population of D. citri was reared in a greenhouse $\left(26^{\circ} \mathrm{C}, 80 \% \mathrm{RH}\right)$ and $14: 10 \mathrm{~h}$ (light:dark) photoperiod. D. citri adults were transferred to cages $(40 \times 40 \times 50 \mathrm{~cm})$ which contained the saplings of $M$. exotica for oviposition and feeding 4 days, the plants with eggs were transferred to new cages. When the eggs hatched, each instar of $D$. citri was collected during the process of growth and tissues of insect dissected from newly emerged adults ( 3 days old). Samples were frozen in liquid nitrogen and stored at $-80{ }^{\circ} \mathrm{C}$ until extraction.

\section{2. $R N A$-seq}

For the small size of D. citri, we concentrated the tissues of the insects by dissecting newly emerged adults ( 3 days old). A total of 2000 antennas (includes a modicum of tissues of heads), 200 heads (remove antennas), 150 thoraxes, 300 legs, 150 abdomens, and 1000 terminal abdomens (cut from the 5th abdominal segments) were collected from males, and the tissues from females had equal numbers. Total RNA of each sample was extracted using TRIzol Reagent (Invitrogen, Waltham, MA, USA). Total RNA of each sample was quantified and qualified by Agilent 2100 Bioanalyzer (Agilent Technologies, Palo Alto, CA, USA), NanoDrop (Thermo Fisher Scientific, Waltham, MA, USA). NEBNext ${ }^{\circledR}$ Ultra $^{\text {TM }}$ RNA Library Prep Kit for Illumina ${ }^{\circledR}$ (Illumina, San Diego, CA, USA) was used for next-generation sequencing library preparations. Then, we employed Agilent 2100 Bioanalyzer (Agilent Technologies, Palo Alto, CA, USA) for library quality evaluation. The libraries were sequenced on an Illumina HiSeq2500 the clean data was assembled by Trinity [62].

\subsection{Identification of the Neuropeptides and Their Putative G-Protein-Coupled Receptors in D. citri}

The amino acid sequences of D. melanogaster, B. mori, N. lugens, C. suppressalis and other arthropods were used as BLAST queries to search for the candidate neuropeptides and neuropeptides receptor genes from $D$. citri transcriptomic data. The E-value threshold for neuropeptides was 10, and the E-value threshold for receptors was $10^{-5}$. The candidate neuropeptides and neuropeptides receptor genes were reconfirmed by means of BLASTX analysis with the non-redundant protein sequence (NR) at NCBI (http: / / www.ncbi.nlm.nih.gov/). 


\subsection{Structure and Domain Analysis}

The open reading frames (ORFs) of the candidate genes were predicted by the ORF finder (http://www.ncbi.nlm.nih.gov/). SignalP 4.1 Server (http://www.cbs.dtu.dk/services/SignalP/) was employed to identify neuropeptide signal peptide [63]. The transmembrane domains of putative neuropeptides receptors genes were notarized by DAS-TMfilter server (http:/ / mendel.imp.ac.at/sat/ DAS/) [64]. Pfam (http://pfam.xfam.org) [65] and Conserved Domains (https://www.ncbi.nlm.nih. gov/Structure/cdd/wrpsb.cgi?) [66] were used to search the domain.

\subsection{Phylogenetic Analysis}

Phylogenetic analysis of $D$. citri neuropeptides receptors was performed by comparing the neuropeptide GPCRs with those of D. melanogaster, B. mori, N. lugens, and other arthropods. For the Drosophila, the CG numbers of the sequences were used, and for the other species the original names of GPCRs in the publications were used, and the names of ligands were added if identified, the amino acid sequences can be seen in Supplementary Text S1. Sequences were aligned by ClustalW [67], and Neighbor-Joining trees were constructed in MEGA6 with 1000 bootstrap replicates [68]. The dendrograms were viewed in FigTree and edited in Adobe PhotoShop CS6.

\subsection{Gene Expression Profiling of the Neuropeptides and Neuropeptide Receptors}

Gene expression levels for each tissues sample of male and female antenna (included a modicum of tissues of heads), head (remove antenna), thorax, leg, abdomen, and abdomen terminal were estimated by RSEM (RNA-Seq by Expectation-Maximization) (v1.2.6) [69]. The expression levels were given as FPKM values (fragments per kilobase of transcript, per million fragments sequenced). Each of the FPKM values were transformed into $\log 2(R P K M+1)$ values, and the expression profiling of the putative genes was generated and visualized by Heatmap Illustrator version 1.0 (http://hemi. biocuckoo.org/) [70]. Differential expression analysis used the DESeq package [71], six genes were selected to verify the accuracy of expression level by qRT-PCR (Supplementary Figure S2). The data analysis was conducted using GraphPad Prism 7.01. Statistical significance was evaluated using a one-way ANOVA followed by Tukey's multiple range test at the 0.05 level.

\subsection{Developmental Stages Expression Analysis}

qRT-PCR was used with SYBR-green fluorescence. Total RNA was extracted from eggs, nymphs (1st to 5th-instars), and adults of one day and five days (sexual maturity) after eclosion. The PrimeScript ${ }^{\mathrm{TM}}$ RT reagent Kit with gDNA Eraser (Takara, Dalian, China) was used for cDNA synthesis following manufacturer's instructions, reference gene Dcitactin-1 was used as the internal controls [72]. The gene-specific primers were designed by Primer 3 program (http:/ / elixir.ut.ee/Main/ Services) [73] (Supplementary Table S2). The qRT-PCR reactions run on a CFX96 Touch $^{\mathrm{TM}}$ Real-Time PCR System (Bio-Rad, California, USA), and the following program was adopted: $95^{\circ} \mathrm{C}$ for $3 \mathrm{~min}$, 40 cycles of $95^{\circ} \mathrm{C}$ for $5 \mathrm{~s}$ and $59^{\circ} \mathrm{C}$ for $30 \mathrm{~s}$, and a final melting cycle (from 60 to $95^{\circ} \mathrm{C}$ ). Each experiment consisted of three biological replicates and three technical replicates. The relative values of mRNA expression were calculated by The $2^{-\Delta \Delta C T}$ method [74]. Data analysis was conducted using GraphPad Prism 7.01. Statistical significance was evaluated using a one-way ANOVA followed by the Tukey's multiple range test at the 0.05 level.

\section{Conclusions}

The main purpose of this study was to identify the genes that encoding neuropeptides and their putative receptors. Transcriptomic analysis of these genes revealed the neuropeptide system in D. citri. In total, 40 neuropeptide and 42 neuropeptide receptor genes were identified. Most of these genes were annotated for the first time in D. citri. The expression of all these genes in different tissues was analyzed based on transcriptome profiling using RNA-seq data. The genes show high 
expression in the antenna and/or abdomen was speculated as representative potential pesticides or targets. Furthermore, these data contain more genes that are appropriate as new pesticides or targets which we did not mention; future research will prove that they are valuable in insect pest management.

Supplementary Materials: Supplementary materials can be found at http:/ / www.mdpi.com/1422-0067/19/12/ 3912/s1.

Author Contributions: Conceptualization, Z.W., W.Z., and X.Z.; Data curation, Z.W. and X.Z.; Formal analysis, Z.W.; Investigation, Z.W. and X.Z.; Methodology, W.Z.; Project administration, X.Z.; Resources, M.S.H. and J.L.; Supervision, X.Z.; Validation, X.Z.; Visualization, Z.W.; Writing—original draft, Z.W.; Writing—review \& editing, Z.W. and W.Z.

Funding: This research was funded by the National Natural Science Foundation of China, 31572314; National Key Research and Development Program of China, 2017YFD0202005; Department of Science and Technology of Guangdong Province, 2015B090903076.

Acknowledgments: We thank Syed Arif Hussain Rizvi and Fajun Tian for editorial assistance on the manuscript, and Xiaoyue Sang for the construction of dendrograms.

Conflicts of Interest: The authors declare no conflict of interest.

\section{References}

1. Menn, J.J.; Borkovec, A.B. Insect neuropeptides: Potential new insect control agents. J. Agric. Food Chem. 1989, 37, 271-278. [CrossRef]

2. Nässel, D.R.; Winther, Å.M.E. Drosophila neuropeptides in regulation of physiology and behavior. Prog. Neurobiol. 2010, 92, 42-104. [CrossRef] [PubMed]

3. Hewes, R.S.; Taghert, P.H. Neuropeptides and neuropeptide receptors in the Drosophila melanogaster genome. Genome Res. 2001, 11, 1126-1142. [CrossRef] [PubMed]

4. Fricker, L.D. Neuropeptide-processing enzymes: Applications for drug discovery. In Drug Addiction: From Basic Research to Therapy; Rapaka, R.S., Sadée, W., Eds.; Springer: New York, NY, USA, 2008; pp. 497-509, ISBN 978-0-387-76678-2.

5. Zupanc, G.K.H. Peptidergic transmission: From morphological correlates to functional implications. Micron 1996, 27, 35-91. [CrossRef]

6. Caers, J.; Verlinden, H.; Zels, S.; Vandersmissen, H.P.; Vuerinckx, K.; Schoofs, L. More than two decades of research on insect neuropeptide GPCRs: An overview. Front. Endocrinol. 2012, 3, 151. [CrossRef] [PubMed]

7. Seinsche, A.; Dyker, H.; Lösel, P.; Backhaus, D.; Scherkenbeck, J. Effect of helicokinins and ACE inhibitors on water balance and development of Heliothis virescens larvae. J. Insect Physiol. 2000, 46, 1423-1431. [CrossRef]

8. Jung, J.W.; Kim, J.H.; Pfeiffer, R.; Ahn, Y.J.; Page, T.L.; Kwon, H.W. Neuromodulation of olfactory sensitivity in the peripheral olfactory organs of the American cockroach, Periplaneta americana. PLoS ONE 2013, 8, e81361. [CrossRef] [PubMed]

9. Ignell, R.; Root, C.M.; Birse, R.T.; Wang, J.W.; Nässel, D.R.; Winther, Å.M.E. Presynaptic peptidergic modulation of olfactory receptor neurons in Drosophila. Proc. Natl. Acad. Sci. USA 2009, 106, 13070-13075. [CrossRef] [PubMed]

10. Verlinden, H.; Vleugels, R.; Zels, S.; Dillen, S.; Lenaerts, C.; Crabbé, K.; Spit, J.; Vanden Broeck, J. Receptors for neuronal or endocrine signalling molecules as potential targets for the control of insect pests. In Advances in Insect Physiology; Cohen, E., Ed.; Academic Press: New York, NY, USA, 2014; pp. 167-303, ISBN 0065-2806.

11. Ons, S. Neuropeptides in the regulation of Rhodnius prolixus physiology. J. Insect Physiol. 2017, 97, 77-92. [CrossRef]

12. Étienne, J.; Quilici, S.; Marival, D.; Franck, A. Biological control of Diaphorina citri (Hemiptera: Psyllidae) in Guadeloupe by imported Tamarixia radiata (Hymenoptera: Eulophidae). Fruits 2001, 56, 307-315. [CrossRef]

13. Grafton-Cardwell, E.E.; Stelinski, L.L.; Stansly, P.A. Biology and management of Asian citrus psyllid, vector of the Huanglongbing pathogens. Annu. Rev. Entomol. 2013, 58, 413-432. [CrossRef] [PubMed]

14. Halbert, S.E.; Manjunath, K.L. Asian citrus psyllids (Sternorrhyncha: Psyllidae) and greening disease of citrus: A literature review and assessment of risk in Florida. Fla. Entomol. 2004, 87, 330-353. [CrossRef]

15. Manjunath, K.L.; Halbert, S.E.; Ramadugu, C.; Webb, S.; Lee, R.F. Detection of 'Candidatus Liberibacter asiaticus' in Diaphorina citri and its importance in the management of Citrus Huanglongbing in Florida. Phytopathology 2008, 98, 387-396. [CrossRef] [PubMed] 
16. Tiwari, S.; Clayson, P.J.; Kuhns, E.H.; Stelinski, L.L. Effects of buprofezin and diflubenzuron on various developmental stages of Asian citrus psyllid, Diaphorina citri. Pest Manag. Sci. 2012, 68, 1405-1412. [CrossRef] [PubMed]

17. Sétamou, M.; Rodriguez, D.; Saldana, R.; Schwarzlose, G.; Palrang, D.; Nelson, S.D. Efficacy and uptake of soil-applied imidacloprid in the control of Asian citrus psyllid and a citrus leafminer, two foliar-feeding citrus pests. J. Econ. Entomol. 2010, 103, 1711-1719. [CrossRef] [PubMed]

18. Tiwari, S.; Mann, R.S.; Rogers, M.E.; Stelinski, L.L. Insecticide resistance in field populations of Asian citrus psyllid in Florida. Pest Manag. Sci. 2011, 67, 1258-1268. [CrossRef] [PubMed]

19. Roller, L.; Yamanaka, N.; Watanabe, K.; Daubnerová, I.; Žitňan, D.; Kataoka, H.; Tanaka, Y. The unique evolution of neuropeptide genes in the silkworm Bombyx mori. Insect Biochem. Mol. Biol. 2008, 38, 1147-1157. [CrossRef] [PubMed]

20. Xu, G.; Gu, G.; Teng, Z.; Wu, S.; Huang, J.; Song, Q.; Ye, G.; Fang, Q. Identification and expression profiles of neuropeptides and their $\mathrm{G}$ protein-coupled receptors in the rice stem borer Chilo suppressalis. Sci. Rep. 2016, 6, 28976. [CrossRef]

21. Li, B.; Predel, R.; Neupert, S.; Hauser, F.; Tanaka, Y.; Cazzamali, G.; Williamson, M.; Arakane, Y.; Verleyen, P.; Schoofs, L.; et al. Genomics, transcriptomics, and peptidomics of neuropeptides and protein hormones in the red flour beetle Tribolium castaneum. Genome Res. 2007, 18, 113-122. [CrossRef]

22. Hummon, A.B.; Richmond, T.A.; Verleyen, P.; Baggerman, G.; Huybrechts, J.; Ewing, M.A.; Vierstraete, E.; Rodriguez-Zas, S.L.; Schoofs, L.; Robinson, G.E.; et al. From the genome to the proteome: Uncovering peptides in the Apis brain. Science 2006, 314, 647-649. [CrossRef]

23. Tanaka, Y.; Suetsugu, Y.; Yamamoto, K.; Noda, H.; Shinoda, T. Transcriptome analysis of neuropeptides and G-protein coupled receptors (GPCRs) for neuropeptides in the brown planthopper Nilaparvata lugens. Peptides 2014, 53, 125-133. [CrossRef] [PubMed]

24. Ons, S.; Sterkel, M.; Diambra, L.; Urlaub, H.; Rivera-Pomar, R. Neuropeptide precursor gene discovery in the Chagas disease vector Rhodnius prolixus. Insect Mol. Biol. 2011, 20, 29-44. [CrossRef] [PubMed]

25. Audsley, N.; Down, R.E. G protein coupled receptors as targets for next generation pesticides. Insect Biochem. Mol. Biol. 2015, 67, 27-37. [CrossRef] [PubMed]

26. Huybrechts, J.; Bonhomme, J.; Minoli, S.; Prunier-Leterme, N.; Dombrovsky, A.; Abdel-Latief, M.; Robichon, A.; Veenstra, J.A.; Tagu, D. Neuropeptide and neurohormone precursors in the pea aphid, Acyrthosiphon pisum. Insect Mol. Biol. 2010, 19, 87-95. [CrossRef] [PubMed]

27. Kim, Y.; Žitňan, D.; Galizia, C.G.; Cho, K.; Adams, M.E. A command chemical triggers an innate behavior by sequential activation of multiple peptidergic ensembles. Curr. Biol. 2006, 16, 1395-1407. [CrossRef] [PubMed]

28. Zitnan, D.; Adams, M.E. Neuroendocrine regulation of ecdysis. In Insect Endocrinology; Gilbert, L.I., Ed.; Academic Press: San Diego, CA, USA, 2012; pp. 253-309, ISBN 978-0-12-384749-2.

29. Kataoka, H.; Toschi, A.; Li, J.P.; Carney, R.L.; Schooley, D.A.; Kramer, S.J. Identification of an allatotropin from adult Manduca sexta. Science 1989, 243, 1481. [CrossRef] [PubMed]

30. Nachman, R.J.; Moyna, G.; Williams, H.J.; Tobe, S.S.; Scott, A.I. Synthesis, biological activity, and conformational studies of insect allatostatin neuropeptide analogues incorporating turn-promoting moieties. Bioorg. Med. Chem. 1998, 6, 1379-1388. [CrossRef]

31. Down, R.E.; Matthews, H.J.; Audsley, N. Effects of Manduca sexta allatostatin and an analog on the pea aphid Acyrthosiphon pisum (Hemiptera: Aphididae) and degradation by enzymes from the aphid gut. Peptides 2010, 31, 489-497. [CrossRef]

32. Matthews, H.J.; Down, R.E.; Audsley, N. Effects of Manduca sexta allatostatin and an analogue on the peach-potato aphid Myzus persicae (hemiptera: Aphididae) and degradation by enzymes in the aphid gut. Arch. Insect Biochem. Physiol. 2010, 75, 139-157. [CrossRef]

33. Mayoral, J.G.; Nouzova, M.; Brockhoff, A.; Goodwin, M.; Hernandez-Martinez, S.; Richter, D.; Meyerhof, W.; Noriega, F.G. Allatostatin-C receptors in mosquitoes. Peptides 2010, 31, 442-450. [CrossRef]

34. Audsley, N.; Vandersmissen, H.P.; Weaver, R.; Dani, P.; Matthews, J.; Down, R.; Vuerinckx, K.; Kim, Y.; Vanden Broeck, J. Characterisation and tissue distribution of the PISCF allatostatin receptor in the red flour beetle, Tribolium castaneum. Insect Biochem. Mol. Biol. 2013, 43, 65-74. [CrossRef] [PubMed]

35. Dong, Y.; Wang, Z.; Jing, T. Functional characterization of ASTC (allatostatin C) and ASTCC (allatostatin double C) in Clostera anastomosis (Lepidoptera: Notodontidae). Gene 2017, 598, 1-8. [CrossRef] [PubMed] 
36. Wu, Q.; Brown, M.R. Signaling and function of insulin-like peptides in insects. Annu. Rev. Entomol. 2006, 51, 1-24. [CrossRef] [PubMed]

37. Kim, S.K.; Rulifson, E.J. Conserved mechanisms of glucose sensing and regulation by Drosophila corpora cardiaca cells. Nature 2004, 431, 316. [CrossRef]

38. Isabel, G.; Martin, J.; Chidami, S.; Veenstra, J.A.; Rosay, P. AKH-producing neuroendocrine cell ablation decreases trehalose and induces behavioral changes in Drosophila. Am. J. Physiol. Regul. Integr. Comp. Physiol. 2005, 288, R531-R538. [CrossRef] [PubMed]

39. Holman, G.M.; Nachman, R.J.; Wright, M.S. Insect neuropeptides. Annu. Rev. Entomol. 1990, 35, $201-217$. [CrossRef] [PubMed]

40. Holman, G.M.; Cook, B.J.; Nachman, R.J. Primary structure and synthesis of a blocked myotropic neuropeptide isolated from the cockroach, Leucophaea maderae. Comp. Biochem. Physiol. Part C Pharmacol. Toxicol. Endocrinol. 1986, 85, 219-224. [CrossRef]

41. Coast, G.M.; Holman, G.M.; Nachman, R.J. The diuretic activity of a series of cephalomyotropic neuropeptides, the achetakinins, on isolated Malpighian tubules of the house cricket, Acheta domesticus. J. Insect Physiol. 1990, 36, 481-488. [CrossRef]

42. Hayes, T.K.; Pannabecker, T.L.; Hinckley, D.J.; Holman, G.M.; Nachman, R.J.; Petzel, D.H.; Beyenbach, K.W. Leucokinins, a new family of ion transport stimulators and inhibitors in insect Malpighian tubules. Life Sci. 1989, 44, 1259-1266. [CrossRef]

43. Nachman, R.J.; Strey, A.; Isaac, E.; Pryor, N.; Lopez, J.D.; Deng, J.; Coast, G.M. Enhanced in vivo activity of peptidase-resistant analogs of the insect kinin neuropeptide family. Peptides 2002, 23, 735-745. [CrossRef]

44. Nachman, R.J.; Coast, G.M.; Douat, C.; Fehrentz, J.; Kaczmarek, K.; Zabrocki, J.; Pryor, N.W.; Martinez, J. A C-terminal aldehyde insect kinin analog enhances inhibition of weight gain and induces significant mortality in Helicoverpa zea larvae. Peptides 2003, 24, 1615-1621. [CrossRef] [PubMed]

45. Smagghe, G.; Mahdian, K.; Zubrzak, P.; Nachman, R.J. Antifeedant activity and high mortality in the pea aphid Acyrthosiphon pisum (Hemiptera: Aphidae) induced by biostable insect kinin analogs. Peptides 2010, 31, 498-505. [CrossRef] [PubMed]

46. Verleyen, P.; Huybrechts, J.; Schoofs, L. SIFamide illustrates the rapid evolution in Arthropod neuropeptide research. Gen. Comp. Endocrinol. 2009, 162, 27-35. [CrossRef] [PubMed]

47. Terhzaz, S.; Rosay, P.; Goodwin, S.F.; Veenstra, J.A. The neuropeptide SIFamide modulates sexual behavior in Drosophila. Biochem. Biophys. Res. Commun. 2007, 352, 305-310. [CrossRef] [PubMed]

48. Lin, Y.; Stormo, G.D.; Taghert, P.H. The neuropeptide pigment-dispersing factor coordinates pacemaker interactions in the Drosophila circadian system. J. Neurosci. 2004, 24, 7951-7957. [CrossRef] [PubMed]

49. Kim, W.J.; Jan, L.Y.; Jan, Y.N. A PDF/NPF neuropeptide signaling circuitry of male Drosophila melanogaster controls rival-induced prolonged mating. Neuron 2013, 80, 1190-1205. [CrossRef] [PubMed]

50. Jiang, H.; Lkhagva, A.; Daubnerová, I.; Chae, H.; Šimo, L.; Jung, S.; Yoon, Y.; Lee, N.; Seong, J.Y.; Žitňan, D.; et al. Natalisin, a tachykinin-like signaling system, regulates sexual activity and fecundity in insects. Proc. Natl. Acad. Sci. USA 2013, 110, E3526-E3534. [CrossRef]

51. Gui, S.H.; Jiang, H.B.; Liu, X.Q.; Xu, L.; Wang, J.J. Molecular characterizations of natalisin and its roles in modulating mating in the oriental fruit fly, Bactrocera dorsalis (Hendel). Insect Mol. Biol. 2017, 26, 103-112. [CrossRef]

52. Leal, W.S.; Choo, Y.M.; Xu, P.; Da Silva, C.S.B.; Ueira-Vieira, C. Differential expression of olfactory genes in the southern house mosquito and insights into unique odorant receptor gene isoforms. Proc. Natl. Acad. Sci. USA 2013, 110, 18704-18709. [CrossRef]

53. Vanden Broeck, J.; Torfs, H.; Poels, J.; Poyer, W.; Swinnen, E.; Ferket, K.; Loof, A. Tachykinin-like peptides and their receptors: A review. Ann. N. Y. Acad. Sci. 1999, 897, 374-387. [CrossRef]

54. Winther, Å.M.E.; Acebes, A.; Ferrús, A. Tachykinin-related peptides modulate odor perception and locomotor activity in Drosophila. Mol. Cell. Neurosci. 2006, 31, 399-406. [CrossRef] [PubMed]

55. Shankar, S.; Chua, J.Y.; Tan, K.J.; Calvert, M.E.; Weng, R.; Ng, W.C.; Mori, K.; Yew, J.Y. The neuropeptide tachykinin is essential for pheromone detection in a gustatory neural circuit. eLife 2015, 4, e6914. [CrossRef] [PubMed]

56. Zdarek, J.; Nachman, R.J.; Denlinger, D.L. Parturition hormone in the tsetse Glossina morsitans: Activity in reproductive tissues from other species and response of tsetse to identified neuropeptides and other neuroactive compounds. J. Insect Physiol. 2000, 46, 213-219. [CrossRef] 
57. Hansen, K.K.; Hauser, F.; Williamson, M.; Weber, S.B.; Grimmelikhuijzen, C.J.P. The Drosophila genes CG14593 and CG30106 code for G-protein-coupled receptors specifically activated by the neuropeptides CCHamide-1 and CCHamide-2. Biochem. Biophys. Res. Commun. 2011, 404, 184-189. [CrossRef] [PubMed]

58. Ida, T.; Takahashi, T.; Tominaga, H.; Sato, T.; Sano, H.; Kume, K.; Ozaki, M.; Hiraguchi, T.; Shiotani, H.; Terajima, S.; et al. Isolation of the bioactive peptides CCHamide-1 and CCHamide-2 from Drosophila and their putative role in appetite regulation as ligands for $\mathrm{G}$ protein-coupled receptors. Front. Endocrinol. 2012, 3, 177. [CrossRef] [PubMed]

59. Farhan, A.; Gulati, J.; Große-Wilde, E.; Vogel, H.; Hansson, B.S.; Knaden, M. The CCHamide 1 receptor modulates sensory perception and olfactory behavior in starved Drosophila. Sci. Rep. 2013, 3, 2765. [CrossRef] [PubMed]

60. Berg, B.G.; Schachtner, J.; Utz, S.; Homberg, U. Distribution of neuropeptides in the primary olfactory center of the heliothine moth Heliothis virescens. Cell Tissue Res. 2006, 327, 385-398. [CrossRef] [PubMed]

61. Utz, S.; Huetteroth, W.; Wegener, C.; Kahnt, J.; Predel, R.; Schachtner, J. Direct peptide profiling of lateral cell groups of the antennal lobes of Manduca sexta reveals specific composition and changes in neuropeptide expression during development. Dev. Neurobiol. 2007, 67, 764-777. [CrossRef]

62. Grabherr, M.G.; Haas, B.J.; Yassour, M.; Levin, J.Z.; Thompson, D.A.; Amit, I.; Adiconis, X.; Fan, L.; Raychowdhury, R.; Zeng, Q.; et al. Full-length transcriptome assembly from RNA-Seq data without a reference genome. Nat. Biotechnol. 2011, 29, 644-652. [CrossRef]

63. Petersen, T.N.; Brunak, S.; von Heijne, G.; Nielsen, H. SignalP 4.0: Discriminating signal peptides from transmembrane regions. Nat. Methods 2011, 8, 785-786. [CrossRef]

64. Cserzo, M.; Eisenhaber, F.; Eisenhaber, B.; Simon, I. On filtering false positive transmembrane protein predictions. Protein Eng. 2002, 15, 745-752. [CrossRef] [PubMed]

65. Finn, R.D.; Coggill, P.; Eberhardt, R.Y.; Eddy, S.R.; Mistry, J.; Mitchell, A.L.; Potter, S.C.; Punta, M.; Qureshi, M.; Sangrador-Vegas, A.; et al. The Pfam protein families database: Towards a more sustainable future. Nucleic Acids Res. 2016, 44, D279-D285. [CrossRef] [PubMed]

66. Marchler-Bauer, A.; Bo, Y.; Han, L.; He, J.; Lanczycki, C.J.; Lu, S.; Chitsaz, F.; Derbyshire, M.K.; Geer, R.C.; Gonzales, N.R.; et al. CDD/SPARCLE: Functional classification of proteins via subfamily domain architectures. Nucleic Acids Res. 2017, 45, D200-D203. [CrossRef] [PubMed]

67. Thompson, J.D.; Higgins, D.G.; Gibson, T.J. CLUSTAL W: Improving the sensitivity of progressive multiple sequence alignment through sequence weighting, position-specific gap penalties and weight matrix choice. Nucleic Acids Res. 1994, 22, 4673-4680. [CrossRef] [PubMed]

68. Tamura, K.; Stecher, G.; Peterson, D.; Filipski, A.; Kumar, S. MEGA6: Molecular evolutionary genetics analysis version 6.0. Mol. Biol. Evol. 2013, 30, 2725-2729. [CrossRef] [PubMed]

69. Li, B.; Dewey, C.N. RSEM: Accurate transcript quantification from RNA-Seq data with or without a reference genome. BMC Bioinformatics 2011, 12, 323. [CrossRef] [PubMed]

70. Deng, W.; Wang, Y.; Liu, Z.; Cheng, H.; Xue, Y. HemI: A toolkit for illustrating heatmaps. PLoS ONE 2014, 9, e111988. [CrossRef]

71. Xu, Y.; Gao, S.; Yang, Y.; Huang, M.; Cheng, L.; Wei, Q.; Fei, Z.; Gao, J.; Hong, B. Transcriptome sequencing and whole genome expression profiling of chrysanthemum under dehydration stress. BMC Genomics 2013, 14, 662. [CrossRef]

72. Wu, Z.; Zhang, H.; Bin, S.; Chen, L.; Han, Q.; Lin, J. Antennal and abdominal transcriptomes reveal chemosensory genes in the Asian citrus psyllid, Diaphorina citri. PLoS ONE 2016, 11, e159372. [CrossRef]

73. Untergasser, A.; Cutcutache, I.; Koressaar, T.; Ye, J.; Faircloth, B.C.; Remm, M.; Rozen, S.G. Primer3-new capabilities and interfaces. Nucleic Acids Res. 2012, 40, e115. [CrossRef]

74. Livak, K.J.; Schmittgen, T.D. Analysis of relative gene expression data using real-time quantitative PCR and the $2^{-\Delta \Delta C T}$ method. Methods 2001, 25, 402-408. [CrossRef] [PubMed]

(C) 2018 by the authors. Licensee MDPI, Basel, Switzerland. This article is an open access article distributed under the terms and conditions of the Creative Commons Attribution (CC BY) license (http://creativecommons.org/licenses/by/4.0/). 